$70: 1112$

<原 著 $>$

アルコール性肝障害における肝酸素需給異常

一肝生検組織所見との対比一

\begin{tabular}{lllllll} 
笠原 彰紀 & 林 & 紀夫 & \multicolumn{2}{l}{ 佐々木 裕 } & 黒沢 & 和平 \\
久保田真司 & 古澤 & 俊一 & 松田 & 裕之 & 八嶌 & 俊 \\
河野 通一 & 房本 & 英之 & 佐藤 & 信紘 & 鎌田 & 武信
\end{tabular}

要 旨：アルコール性肝障害における肝酸素需給動熊と肝組織变化との関連について検討し た.

肝局所血液量は, 肝線維化，肝細胞壊死の程度と負の相関関係が認められた。しかし，脂肪 浸潤，炎症の程度，肝細胞面積とは相関関係は認められなかった．線維化の認められない7例 の解析では，肝局所血夜量は脂肪浸潤の増強に伴い低下した。 また，肝局所 $\mathrm{Hb}$ の酸素飽和度， 肝局所 in vivo 酸素消費も線維化执よび肝細胞壊死が増強する程低下したが，脂肪浸潤・炎症の 程度とは相関関係がみられなかった。

以上，アルコール性肝障害に怙ける肝血流の低下には，病初期は脂肪漫潤の増強が寄与する が，ひとたび線維化がおこると線維化が進展するほど，また肝細胞壊死が増強するほど肝血流 は低下すること，さらに肝酸素消費も線維化の進展・肝細胞壊死の拡がりとともに低下するこ とが明らかとなった。

索引用語： 反射スペクトル アルコール性肝障害 肝血流肝酸素消費

肝線維化

\section{緒 重}

フルコール性肝障害では酸素分圧が最も低いと考え られる肝小葉中心域に脂肪浸潤，線維化，壊死が認め られる(13)ことより肝眼における酸素需給の異常をて ルコール性肝障害の一因とする考えがある。著者らは 藏器反射スベクトル解析法を用い，ヒトてルコール性 肝障害においてて肝局所血液量, 肝酸素消費が非特異性 变化, 肝線維症, 肝硬変症と肝病変が進展することに より，また脂肪漫潤を伴らことにより低下することを すでに明らかにした ${ }^{4,5)}$.

アルコール性肝障害においてては類洞床の狭小化がし ばしば認められ，その原因としては肝細胞内に水分，

電解質, 脂肪, 蛋白質等が詝留し ${ }^{6,7}$ 肝細胞腫大がおこ り類洞を压迫すると考えられている8)。他の原因とし ては，病初期より Disse 腔に膠原線維が沈着すること によりおこる肝細胞周囲の線維化があげられて,3,9)，両

- 大阪大学第 1 内科

〈受付日 60年11月27日 $>$
者とも肝血流の低下の原因となりらる。そこで今回， 肝酸素需給異常に最も奇与する肝組織所見の異常を明 らかにするため, 臓器反射スベクトル解析法にて測定 した肝局所血液量, 肝局所 $\mathrm{Hb}$ 酸素飽和度, 旰酸素消費 と肝生検組織の異常の程度との関係を検討した。 対象ならびに方法

日本酒に換算して毎日 5 合10年以上领酒を継続した 41例を対象とし, 全例とも輸血歴, 肝炎の既往は認め ず血清 HBs 抗原はRIA 法にて陰性であった。診断は 入院後14士3 日（禁酒期間）に施行した腹腔鏡・肝生 検にて行い,「アルコールと肝」研究班の分類 ${ }^{101}$ に基つ いた肝組織像の内訳は，非特異性変化 3 例，脂肪肝 4 例, 肝線維症16例, 肝硬变症17例, アルコール性肝炎 1 例であった。

肝局所血行動態・酸素需給動態の検討には既報の朖 器反射スベクトル解析装置を用い, 肝局所血液量 $\left(\Delta \mathrm{Er}_{\text {569-650 }}\right)$, 肝局所 $\mathrm{Hb}$ 酸素飽和度 $\left(\mathrm{SO}_{2}\right)$, 肝局所 in vivo 酸素消費 $\left(\mathrm{VO}_{2}\right)$ を既報の如く算出した4,5,11,12). 肝生検組織は $10 \%$ ホルマリンにて固定後, 厚さ $5 \mu$ に 
カットし，H-E 染色およびAzan-Mallory 染色を行っ た．肝組織変化の程度は，甈器反射スベクトル法の結 果を知らない病理医が肝細胞壊死, 線維化, 炎症, 脂 肪浸潤の程度を 0 から 3 十の 4 段階に分類した (Table 1).

肝細胞面積はIBAS-II (Carl Zeiss, 西ドイッ) を用 い500倍の倍率で線維化，炎症所見のみられない門脈域
上り離れた部位 7 カ所にて湘定した。 上記の条件を満 たすためには，ょり大きな生検試料を必要とするため, 41生検試料中 24 試料においての及解析が可能であっ た。肝細胞面積は $160 \times 160 \mu \mathrm{m}$ の画面上より明らかな 類洞床面積を诚し，その後肝細胞数にて除することよ り求めた。この方法にて算出した肝細胞面積は，肝細 胞を直接トレースして測定した実測値とよく一致し

Table 1 Grading of liver morphology on light microscopy.

\begin{tabular}{|c|c|}
\hline necrosis: & $\begin{array}{l}0 \text {, little or no necrosis in any area of the hepatic lobule } \\
1+\text {, hepatocellular necrosis in zone } 3 \text { or erosion of the limiting } \\
\text { plate } \\
2+\text {, widespread hepatocellular degeneration, some disorganiza- } \\
\text { tion of the liver cell plate } \\
3+\text {, diffuse necrosis, distortion of lobular organization, confluent } \\
\text { hepatocellular degeneration }\end{array}$ \\
\hline fibrosis: & $\begin{array}{l}\text { 0, little or no fibrosis in any area of the hepatic lobule } \\
1+\text {, increased connective tissue found only around the central } \\
\text { veins and adjacent sinusoids } \\
2+\text {, parenchymal fibrosis radiating from the portal triads and } \\
\text { central veins, but without bridging between them } \\
3+\text {, thick fibrosis with nodular formation }\end{array}$ \\
\hline inflammation : & $\begin{array}{l}0 \text {, little or no infiltration of mononuclear and polymorphonu. } \\
\text { clear cells in any area of the hepatic lobule } \\
1+, \text { zonal localization } \\
2+, \text { moderate, not confined to one zone of the lobule } \\
3+, \text { diffuse } \\
0, \text { little fat droplet in any area of the hepatic lobule } \\
1+, \quad<25 \% \text { of cells contain fat droplet } \\
2+, \quad 25-50 \% \\
3+, \quad>50 \%\end{array}$ \\
\hline
\end{tabular}

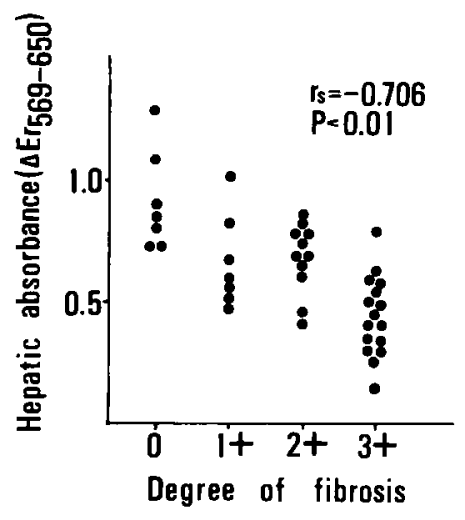

Fig. 1 Correlation between the concentration of hemoglobin in the hepatic tissue, expressed as $\Delta \mathrm{Er}_{569-650}$, and the degree of fibrosis in the whole group of patients with alcoholic liver disease $\left(r_{s}=-0.706, p<0.01\right)$.

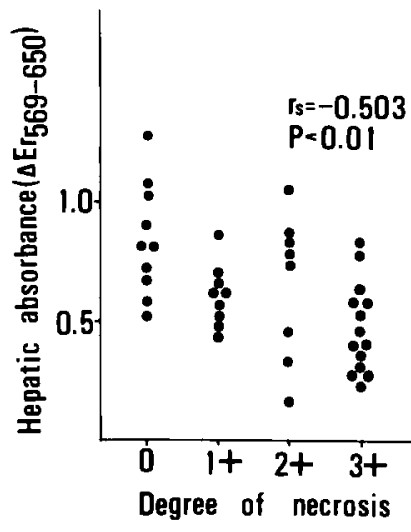

Fig. 2 Correlation between the concentration of hemoglobin in the hepatic tissue and the degree of hepatocyte necrosis in the whole group of alcoholic patients $\left(r_{s}=-0.503, p<0.01\right)$. 
た. 同一生検試料中で測定された肝細胞数のばらつき は9\%以内であった。

肝局所血液量, 肝局所 $\mathrm{Hb}$ 酸素飽和度, 肝局所 in vivo 酸素消費と肝生検組織の变化の程度との関係は Spearman's nonparametric statistics にて検定し，訮 局所血液量と肝細胞面積との関係は linear bivariate

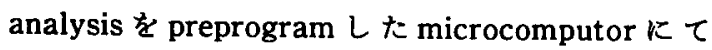
行った.

\section{成 績}

1) 肝局所血液量 $\left(\Delta \mathrm{Er}_{569-650}\right)$ 上肝組織変化

全症例に拈いて肝局所血液量 $\left(\Delta \mathrm{Er}_{569-650}\right)$ と肝組織 変化の程度との関係を検討すると, Fig. 1に示す様に 肝局所血液量と肝葴の線維化の程度との間には有意の 負の相関関係 $\left(r_{s}=-0.706, p<0.01\right)$ がみられ, 線維
化が小葉中心域にのみ限局する段階より肝局所血液量 は低下していた。 また，肝局所血液量と肝細胞壊死の 程度との間にも負の相関関係 $\left(r_{s}=-0.503, p<0.01\right)$ が認められ，肝細胞壊死が広範囲となれば肝局所血液 量は低下した（Fig. 2)。他方，肝局所血液量と炎症や 脂肪浸潤の程度との間には相関関係は認められなかっ た (Fig. 3).

症例を線維化の認められない7 症例に限ると, 肝局 所血液量と脂肪浸潤の程度との間に負の相関関係 $\left(r_{s}=-0.736, p<0.05\right)$ がみられた（Fig. 4).

2) 肝局所血液量 ( $\Delta \mathrm{Er}_{\text {569-650 }}$ ) と肝細胞面積

フルコール性障害肝の肝細胞面積は425より1,200 $\mu \mathrm{m}^{2}$ の間に分布し, 非アルコール性肝疾患の肝細胞面 積に比し著明に腫大していた。この肝細胞面積と肝局
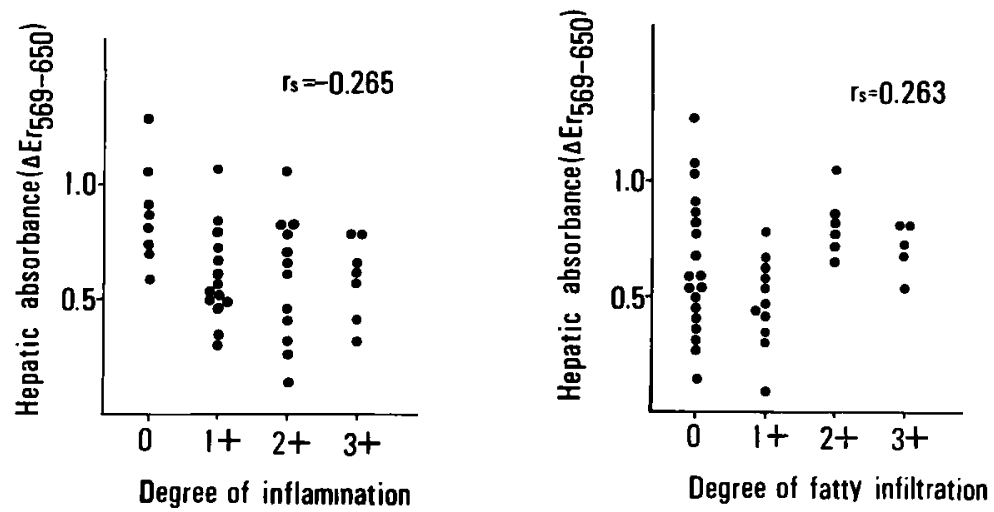

Fig. 3 Lack of correlation between the concentration of hemoglobin in the hepatic tissue and the degree of fatty infiltration (right) or of inflammation (left) in the whole patients.

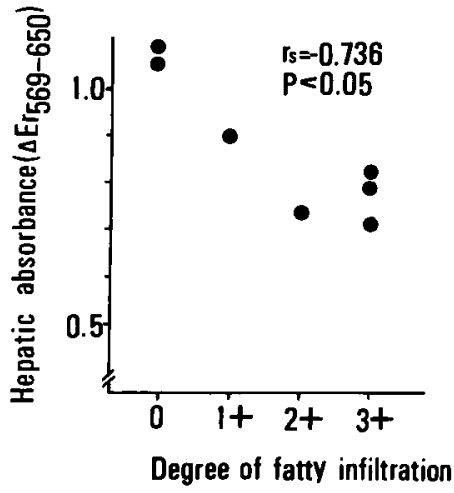

Fig. 4 Correlation between the concentration of hemoglobin in the hepatic tissue and the degree of fatty infiltration in patients without liver fibrosis $\left(r_{s}=-0.736, p<0.05\right)$.

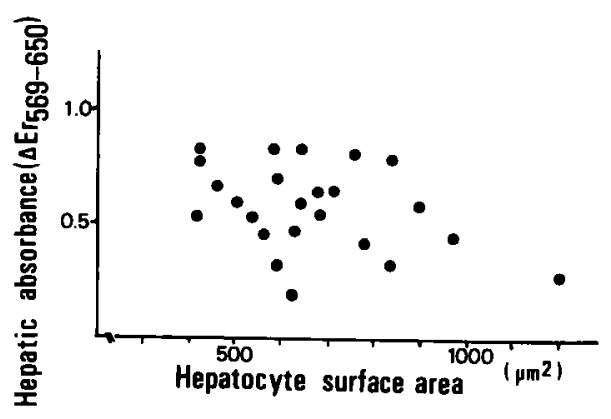

Fig. 5 Correlation between the concentration of hemoglobin in the hepatic tissue and the size of hepatocyte, measured as surface area. There was no significant correlation between them. 

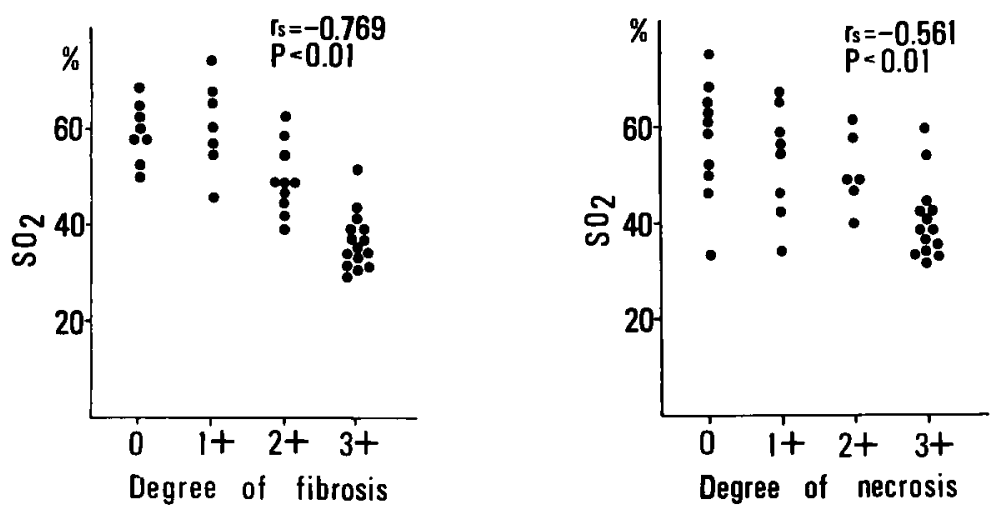

Fig. 6 Correlation between the estimated oxygen saturation of hemoglobin in the hepatic tissue $\left(\mathrm{SO}_{2}\right)$ and the degree of fibrosis (left) or of hepatocyte necrosis (right). $\left(r_{s}=-0.769, p<0.01 ; r_{s}=-0.561, p<0.01\right)$.
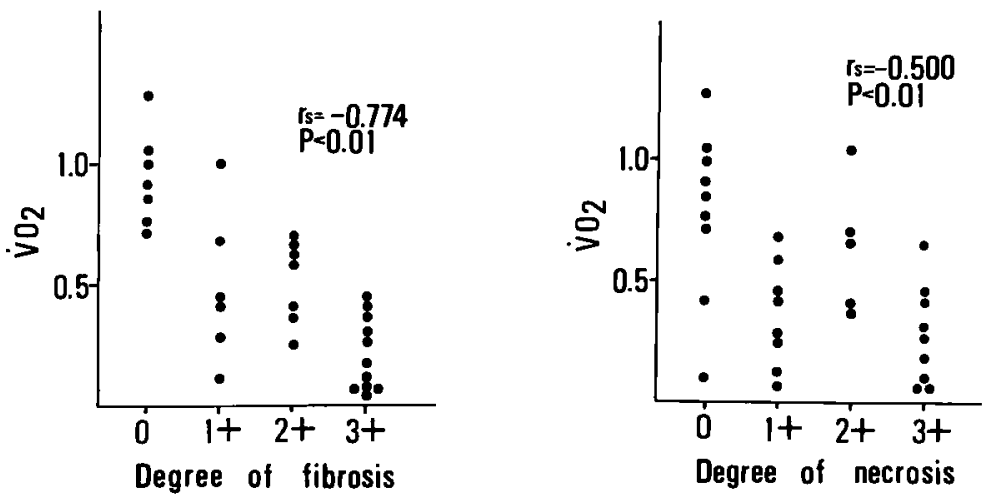

Fig. 7 Relationship between the in vivo hepatic oxygen consumption $\left(\dot{\mathrm{V}}_{2}\right)$ and the degree of fibrosis (left) or of hepatocyte necrosis (right) $\left(r_{s}=-0.774, p<\right.$ $0.01 ; r_{9}=-0.500, p<0.01$ ).

所血液量との関係を検討すると，Fig. 5に示す様に両 者には相関関係がみられなかった。

3) 肝局所 $\mathrm{Hb}$ 酸素飽和度 $\left(\mathrm{SO}_{2}\right)$ 之肝組織変化 肝局所 $\mathrm{Hb}$ 酸素飽和度 $\left(\mathrm{SO}_{2}\right)$ と肝組織变化の程度 と の関俰を検討すると，Fig. 6左に示す様に肝局所 $\mathrm{Hb}$ 酸素飽和度と線維化の程度との間には有意の負の相関 関係 $\left(\mathrm{r}_{\mathrm{s}}=-0.709, \mathrm{p}<0.01\right)$ がみられたが, 訮局所 $\mathrm{Hb}$ 酸素飽和度の低下は, 線維化が軽度の段階では著明で なく，結節形成の様な強い線維化がみられる段階で著 明に低下した。 また肝局所 $\mathrm{Hb}$ 酸素飽和度と肝細胞壊 死の程度之の間にも Fig. 6右に示す様に負の相関関 係 $\left(r_{s}=-0.561, p<0.01\right)$ が認められた。他方，肝局 所 $\mathrm{Hb}$ 酸素館和度と炎症や脂肪浸潤の程度との間には 相関関係はみられなかった。

4) 肝局所 in vivo 酸素消費 $\left(\mathrm{V}_{2}\right)$ と肝組織変化
実際の肝細胞の機能維持・発現に重要な意味をるつ 肝局所 in vivo 酸素消費 $\left(\mathrm{VO}_{2}\right)$ と肝組織变化の程度と の関係を検討すると，Fig. 7左に示す様に肝局所 in vivo酸素消費と線䊒化の程度との間には有意の負 $\left(r_{s}=-0.774, p<0.01\right) の, F i g .7$ 右に示す様に肝細胞 罗死の程度とも有意の負 $\left(r_{s}=-0.500, p<0.01\right)$ の相 関関保が認められた。他方, 肝局所 in vivo 酸素消費と 炎症・脂肪漫潤の程度との間には相関関保が認められ なかった。

\section{考按}

我々は䑏器反射スベクトル解析装置を用い類洞床の へモグロビンの定量，酸素化動態を検索することによ ク，フルコール性肝障害においては肝局所血流の指標 である肝局所血液量が非特異性変化, 肝線維症, 肝硬 変症と肝病変が進展するのに伴い，また脂肪浸潤を伴 
らことにより低下すること4)，同時に肝酸素消費も低 下することらすすでに明らかにした。

アルコール性肝障害では肝細胞腫大6-8)中 Disse 腔 の膠原線䧽の増加による肝細胞周囲の線維化,2,39)がし ばしば認められ、これらは類洞床の狭小化や肝細胞へ の substrate の移行を障害する ${ }^{13,14)}$ 原因となりらる。 そこで今回，肝酸素需給異常に最も寄与する肝組織変 化について検討した。

全症例に括いて肝組織変化の程度と肝局所血流の指 標である肝局所血液量 $\left(\Delta \mathrm{Er}_{569-650}\right)$ との関俰を検討す ると，肝局所血流は線維化が小菓中心域に限局する段 階より低下し，線維化が進展するのに伴い低下した。 また肝細胞壊死が広範囲となればなる程肝局所血流は 低下した。この結果は, 肝細胞壊死のみられるマルコー ル性肝障害では肝細胞壊死のみられない例に比し肝血 流が低下するという Iturriaga らの報告15)とも一致 し, 肝血流の低下が肝細胞壊死に密接に関与すると考 之られた，他方，肝局所血流と炎症・脂肪浸潤の程度 との間には相関関係がみられなかった。

線維化のみられない症例に招いて肝局所血流の低下 の原因を検索すると，肝細胞腫大を来たすと考えられ る脂肪浸潤の增強に伴い肝局所血流は低下した。

Orrego らは光顕的に線維化がみられず,脂肪肝と診断 した症例の中に電䫓的に Disse 腔の膠原線維が増加し ている症例がみられ，この様な症例では肝機能が著し く障害されると報告している9．著者らの症例では電 顕による恰索は行っていないが，光顕上楾維化が認め られないとした症例では GOT $64 \pm 63 \mathrm{iu} / l, \mathrm{GPT} 66 \pm$

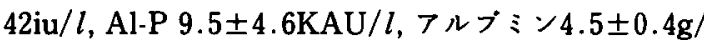
$\mathrm{d} l$, プロトロンビン時間 $98 \pm 13 \%$, ICG $\mathrm{R}_{15} 7.4 \pm 3.4 \%$ と血清トランスフミナーゼ値が軽度上昇していたのみ で，他の肝機能検查値はほぼ正常域であったことより Disse 腔の膠原線維が増加している可能性は少ないと 思われた。従って線維化の認められない段階では，脂 肪漫潤による肝細胞腫大が類洞床の狭小化を来たすた め肝血流が低下すると考えられた。

アルコール性障害肝に拈ける肝細胞面積の測定は上 $ヒ^{16)}$ ，ヒト ${ }^{8,17)}$ ，で報告されている，ヒヒに沶いては脂 肪肝, 脂肪肝十線維化の段階で中心静脈域，中間域の 肝細胞は腫大し，門脈域の肝細胞は腫大しないとされ ている16).ヒトに扣ける検討では, 非アルコール性肝疾 患の肝細胞に比しフルコール性障害肝の肝細胞は著明 に腫大し，その結果頑洞床の㹟小化を来たすと報告さ れている゙．今回の著者らの検討でも肝細胞は425より
$1,200 \mu \mathrm{m}^{2}$ の間に分布し，従来の報告にみられる様に正 常㧍よび非フルコール性肝疾患に比し著明に腫大して いた，そこで，肝局所血流と肝細胞面積との関係を娭 討すると両者には相関関係がみられなかった，以上の 様に, アルコール性肝障害では病初期の線維化がみら れない時期には肝細胞腫大による類洞床の狭小化によ ク，ひとたび線維化がょこれば脂肪漫潤や肝細胞腫大 よりは線維化の進展が肝血流の低下に寄与すると考え られた。

実際の肝細胞機能の維持・発現に重要な肝局所 in vivo 酸素消費 $\left(\mathrm{VO}_{2}\right)$ と肝組織変化との関係を検討す ると，線維化の程度と肝局所 in vivo酸素消費の間に は負の相関関係がみられ，線維化の増強に伴い肝局所 in vivo 酸素消費は低下した。 また，肝細胞壊死の範囲 が広範囲となればなる程，肝局所 in vivo酸素消費は 低下した。

肝局所 $\mathrm{Hb}$ 酸素飽和度 $\left(\mathrm{SO}_{2}\right)$ と旰組織変化との関係 を検討すると，線維化の程度と肝局所 $\mathrm{Hb}$ 酸素飽和度 との間には負の相関関係が認められた。しかし，肝局 所 $\mathrm{Hb}$ 酸素飽和度は線維化が小葉中心域にの 又限局す る段階では，線維化の認められない例と同程度であっ た。これは Fig. 7に示す様に肝局所 in vivo 酸素消費 が，線維化が小葉中心域に限局する段階より著明に低 下しているためと考えられた。

以上, アルコール性肝障害に补ける肝血流の低下に, 病初期には脂肪漫潤が寄与するが，ひとたび線維化が 認められるようになると脂肪浸潤や肝細胞腫大による 類洞床の狭小化よりは線維化の増悪が密接に奇与する ことが明らかとなった。 また，肝酸素消費も肝臓の線 維化の進展・刵細胞壊死の増強に伴い低下した。この 様な肝酸素需給の異常が，アルコール性肝障害におけ る病変のより一層の進展に奇与することが示唆され た。

\section{文献}

1) Edmondson H, Peters RL, Frankel $\mathrm{HH}$, et al : The early stage of liver injury in the alcoholic. Medicine 46: 119-129, 1976

2) Van Waes L, Lieber CS: Early perivenular sclerosis in alcoholic fatty liver: an index of progressive liver injury. Gastroenterology 73 : 646-650, 1977

3) Nakano M, Worner TM, Lieber CS: Perivenular fibrosis in alcoholic liver injury: Ultrastructure and histologic progression. Gas- 
troenterology $83: 777-785,1982$

4) Hayashi N, Kasahara A, Kurosawa $K$, et al : Oxygen supply to the liver in patients with alcoholic liver disease assessed by organ-reflectance spectrophotometry. Gastroenterology $88: 881-886,1985$

5）笠原彰紀, 林 紀夫, 黒沢和平, 他：フルコール性 肝席害における肝酸素需給動態の検討．肝荿 $26: 182-188,1985$

6) Baraona E, Leo MA, Borowsky SA, et al: Pathogenesis of alcohol-induced accumulation in the liver. J Clin Invest $60: 546-554,1977$

7) Israel $Y$, Khanna JM, Orrego $H$, et al : Studies on metabolic tolerance to alcohol, hepatomegaly and alcoholic liver disease. Drug and Alcohol Dependence 4 : 109-118, 1979

8) Vidins EI, Britton RS, Medline A, et al: Sinusoidal caliber in alcoholic and nonalcoholic liver disease: Diagnostic and pathogenic implications. Hepatology $5: 408-414,1985$

9) Orrego H, Medline L, Blendis LM, et al: Collagenisation of the Disse space in alcoholic liver disease. Gut $20: 673-679,1985$

10）武内重五郎, 奥平雅彦, 高田 昭, 他：わが国にお けるフルコール性肝障害の実態一全国集計の成績 から. 日消誌 $76: 2178-2185,1979$

11) Sato $N$, Hayashi $N$, Kawano $S$, et al : Hepatic hemodynamics in patients with chronic he- patitis or cirrhosis as assessed by organreflectance spectrophotometry. Gastroenterology $84: 611-616,1983$

12) Kamada T, Hayashi $N$, Sato $N$, et al : Estimated hepatic oxygen consumption in patients with chronic liver disease as assessed by organ-reflectance spectrophotometry. Dig Dis Sci $31: 119-124,1986$

13) Schaffner F, Popper H: Capillarization of hepatic sinusoids in man. Gastroenterology 44 : 239-242, 1963

14) Mak KM, Lieber CS: Alterations in endotherial fenestrations in liver sinusoids of baboons fed alcohol: A scanning electron microscopic study. Hepatology $4: 386-391,1984$

15) Iturriaga $H$, Ugarte $G$, Israel $Y$ : Hepatic vein oxygenation, liver blood flow and the rate of ethanol metabolism in recently abstinent alcoholic patients. Eur J Clin Invest $10: 211-218$, 1980

16) Miyakawa H, Iida S, Leo MA, et al: Pathogenesis of precirrhotic portal hypertension in alcohol-fed baboons. Gastroenterology $88: 143$ $-150,1985$

17) Blendis LM, Orrego H, Crossley IR, et al : The role of hepatocyte enlargement in hepatic pressure in cirrhotic and non-cirrhotic alcoholic liver disease. Hepatology $2: 539-546,1982$ 


\title{
Correlation between hepatic hemodynamics and abnormality of liver morphology in patients with alcoholic liver disease
}

\author{
Akinori Kasahara, Norio Hayashi, Yutaka SaSaKi, Kazuhei Kurosawa, Shinji Kubota, \\ Shunichi Furusawa, Hiroyuki Matsuda, Takashi Yashima, Michikazu Kono, \\ Hideyuki FUSAMOTO, Nobuhiro SATo and Takenobu KAMADA*
}

Relationship between hepatic hemodynamics estimated by reflectance spectrophotometry and abnormality of liver morphology was investigated in 41 patients with alcoholic liver disease. The index of liver blood flow and the in vivo hepatic oxygen consumption correlated negatively with the degree of fibrosis and of hepatocyte necrosis in the whole group. On the other hand, they correlated neither the degree of fatty infiltration nor inflammation. Moreover, no significant correlation was found between the index of liver blood flow and the size of hepatocyte. When alcoholic patients without liver fibrosis were separately analyzed, there was a negative correlation between the index of liver blood flow and the degree of fatty infiltration.

Thus, the main factor responsible for a decrease in liver blood flow was the fatty infiltration at an early stage of alcoholic liver disease and later, when the disease was advanced, it was the deterioration of fibrosis.

- First Department of Medicine, Osaka University Medical School (Osaka) 